\title{
Study on assessment of proximate composition and meat quality of fresh and stored Clarias gariepinus and Cyprinus carpio
}

\author{
S. Mahboob ${ }^{a, b *}$, K. A. Al-Ghanim ${ }^{a}$, H. F. Alkahem Al-Balawi ${ }^{a}$, F. Al-Misned ${ }^{a}$ and Z. Ahmed ${ }^{a}$ \\ aDepartment of Zoology, College of Science, King Saud University, P.O. Box 2455, Riyadh 11455, Saudi Arabia \\ ${ }^{b}$ Department of Zoology, Government College University, Allama Iqbal Road, Faisalabad-38000, Pakistan \\ *e-mail: shahidmahboob60@hotmail.com
}

Received: November 9, 2017 - Accepted: March 22, 2018 - Distributed: November 30, 2019

\begin{abstract}
The organoleptic evaluation and proximate analysis of Clarias gariepinus and Cyprinus carpio were determined in fresh fish and when refrigerated at two different temperatures $\left(-21^{\circ} \mathrm{C}\right.$ and $\left.4{ }^{\circ} \mathrm{C}\right)$ for a period of six weeks. A panel of twelve trained judges evaluated the color (live), texture, softness and flavor of fish meat after two minutes' steam cooking. Average score revealed a general decline in organoleptic properties such as color, texture, freshness, and taste of C. gariepinus and C. carpio stored at two temperatures compared to the fresh fish. Proximate analysis revealed a more decrease in crude protein and lipid contents and increase in ash content in C. gariepinus and C. carpio at the two storage temperatures compared to the fresh fish muscle. Moisture content decreased in the fish muscle samples of both the fish species stored at $-21{ }^{\circ} \mathrm{C}$ but increased in the $4{ }^{\circ} \mathrm{C}$ stored samples. $\mathrm{pH}$ of fish was found to increase in the two stored temperatures. There were significant differences $(\mathrm{P}<0.05)$ in the organoleptic and proximate composition of the ice stored and fresh $\mathrm{C}$. gariepinus and $\mathrm{C}$. carpio, the same temperature and between the two different temperatures. The quality of fish muscle stored at $4{ }^{\circ} \mathrm{C}$ deteriorated faster than that of the $-21{ }^{\circ} \mathrm{C}$. Thus, storage temperature and duration have adverse effects on the nutritional quality of fish meat.
\end{abstract}

Keywords: Clarias gariepinus, Cyprinus carpio, organoleptic evaluation, proximate analysis, different temperatures.

\section{Estudo da avaliação da composição centesimal e da qualidade da carne de Clarias gariepinus e Cyprinus carpio}

\section{Resumo}

A avaliação organoléptica e a análise aproximada de Clarias gariepinus e Cyprinus carpio foram determinadas em peixe fresco e refrigerado a duas temperaturas diferentes $\left(-21^{\circ} \mathrm{C} \mathrm{e} 4^{\circ} \mathrm{C}\right)$ por um período de seis semanas. Um painel de doze juízes treinados avaliou a cor (ao vivo), textura, maciez e sabor da carne de peixe após dois minutos de cozimento a vapor. $\mathrm{O}$ escore médio revelou um declínio geral nas propriedades organolépticas, como cor, textura, frescor e sabor de C. gariepinus e C. carpio armazenados a duas temperaturas em comparação com o peixe fresco. A análise imediata revelou uma maior diminuição nos teores de proteína bruta e lipídios e aumento no teor de cinzas em C. gariepinus e C. carpio nas duas temperaturas de armazenamento em comparação com o músculo do peixe fresco. O teor de umidade diminuiu nas amostras de músculo de peixe de ambas as espécies de peixes armazenadas a $-21{ }^{\circ} \mathrm{C}$, mas aumentou nas amostras armazenadas a $4{ }^{\circ} \mathrm{C} . \mathrm{O} \mathrm{pH}$ dos peixes aumentou nas duas temperaturas armazenadas. Houve diferenças significativas $(\mathrm{P}<0,05)$ na composição organoléptica e próxima do gelo armazenado e fresco $\mathrm{C}$. gariepinus e $\mathrm{C}$. carpio, a mesma temperatura e entre as duas temperaturas diferentes. A qualidade do músculo do peixe armazenado a $4{ }^{\circ} \mathrm{C}$ deteriorou-se mais rapidamente do que a temperatura de $-21{ }^{\circ} \mathrm{C}$. Assim, a temperatura e duração do armazenamento têm efeitos adversos na qualidade nutricional da carne de peixe.

Palavras-chave: Clarias gariepinus, Cyprinus carpio, avaliação organoléptica, análise aproximada, diferentes temperaturas.

\section{Introduction}

Presently people are more sensitive to healthy eating than in the past (Oriakpono et al., 2011). People prefer white meat like fish over to red meat due to its high nutritional contents (Mahboob et al., 1996; Ayisi et al., 2017). Aquaculture practices are considered today as one of the most promising sources of animal protein. In the recent past fish culture is a newly developed sector in developing countries due to economic returns to commercial fish farmers. A reason for the slow increase in expansion of freshwater fish culture practices was due to lack of research, awareness, technical inputs and advisory services for the farmers (Mahboob, 2014). Fish and shellfish contain 
about $19 \%$ protein similar in amino acid composition to that found in muscle meats. The protein content varies up to $20 \%$, depending upon the species and the season of the year. Fish contains a considerably lower fat content than beef (Nargis, 2006; Ndome et al., 2010a; Al-Ghanim, 2016; Tsironi and Taoukis, 2017). Iheanacho et al. (2017) reported a reduction in moisture content and higher protein content in fish after smoking.

Nutritional quality and organoleptic acceptability in terms of color, texture, smell, flavor and appearance may be affected by the environmental degradation and quality of nutrition and feed provided during culture, especially in semi-intensive and intensive culture systems compared to wild fish (Thomas, 1973; Gram and Huss, 1996; Grigorakis et al., 2003). Freshness quality includes all parameters related to appearance, taste, odor, flavor, and texture which can effect on consumer before purchase of fish (Al-Ghanim, 2016). Hence, fish freshness is very important to evaluate before fish is sold to the consumer. Meyers (1975) reported the characteristics of off-flavor of freshwater fish cultured by feeding treatments and quality of water chemistry with special reference to consumer likeness instead of traditional parameters such as flavor, taste and appearance. The fish meat may be spoiled due to various metabolic changes that regress fish quality and made it unacceptable and unsuitable for human eating because of changes in flavor, taste, and biochemical properties (Ndome et al., 2010b; Al-Ghanim, 2016). The noxious smells of spoiled fish are suspected to be produced by microbes to repulse large animals, thus reserving the food resource for them while increasing spoilage and reducing organoleptic properties (Sherratt et al., 2006; Braun and Sutherland, 2005; Mahboob et al., 2004; Agbabiaka et al., 2016). Sahu et al. (2016) reported extra good quality immediately after the harvest, thereafter gradual deterioration during transportion under cold chain and at the retail shop in Catla catla. Mchazime and Kapute (2018) mentioned that the processed fish were liked by the consumers up to 12 hours of ambient storage. They also reported a significant correlation between sensory scores and storage time at ambient temperature and suggested the time is important factor in maintain the freshness and quality of fish meat. Due to the increase in fish consumption, there seems to be a habit of storage for a long period with an assumption, that the fish maintains the nutritional quality and safe for human consumption. The main aim of this study was to determine overall changes in proximate composition and organoleptic quality of the flesh of Clarias gariepinus and Cyprinus carpio in fresh and stored at two temperature conditions $\left(-21^{\circ} \mathrm{C}\right.$ and $\left.4{ }^{\circ} \mathrm{C}\right)$.

\section{Material and Methods}

\subsection{Sample collection and preparation}

Seven fish samples with three replicates of Clarias gariepinus (C. gariepinus) and Cyprinus carpio (C. carpio) with an average weight of 1200-1500 g were procured from the local market. The fish were gutted and washed with the tap water. The sampled fish was dressed and cut down into two halves; one was used for the proximate analysis and the other for organoleptic evaluation. The standard guidelines for animal experiments prepared by the department and the university were followed in this study.

\subsection{Proximate analysis}

The moisture, protein, lipid and ash content of the fish samples were determined by following method as described by the AOAC (2000).

\subsection{Organoleptic assessment}

The sensory properties of the ice stored and fresh (ambient temperature) C. gariepinus and C. carpio were evaluated by a panel of 12 trained Judges selected from the Department of Food Sciences, and Department of Zoology. Assessment of color, texture, freshness and taste were based on both cooked and uncooked fish samples. Questionnaires for the panelists were prepared using the modified 5- point hedonic scale described by Eyo (2001) as follows: 1-1.9, Unacceptable; 2-2.9, Fair; 3-3.9, Medium; 4-4.9, Good; 5-6.0, Very good.

\subsection{Statistical analysis}

The data were analyzed through analysis of variance by using software Minitab version 15. The means were compared to see the differences with the help of Tukey's test.

\section{Results}

\section{1. $p H$}

There were significant changes in $\mathrm{pH}$ levels of the meat of C. carpio and C. gariepinus with time. The $\mathrm{pH}$ of fish stored at $-21{ }^{\circ} \mathrm{C}$ decreased to $6.79 \pm 0.34$ and $6.82 \pm 0.24$ after one week of storage of C. carpio and C. gariepinus, respectively. After third week it started rising at the end of sixth week final $\mathrm{pH}$ was recorded as $7.05 \pm 0.39$ and $7.21 \pm 0.43$ in C. carpio and C. gariepinus, respectively. The $\mathrm{pH}$ of fish at $4{ }^{\circ} \mathrm{C}$ was decreased to $6.81 \pm 0.25$ and $6.85 \pm 0.25$ after one week of storage of $C$. carpio and $C$. gariepinus, respectively. Later on, after the third week it started rising and final $\mathrm{pH}$ was determined at the end of the sixth week as $7.31 \pm 0.41$ and $7.32 \pm 0.40$ in C. carpio and C. gariepinus, respectively. The fish sample was observed to reduce in acidity, while tending towards an alkaline state with an increase in storage period. Statistical analysis revealed significant differences $(\mathrm{P}<0.05)$ in $\mathrm{pH}$ levels in C. carpio and C. gariepinus stored at the $4{ }^{\circ} \mathrm{C}$ temperature and between the two temperatures (Table 1). The $\mathrm{pH}$ increased with an increasing storage time. The increase was higher at $4{ }^{\circ} \mathrm{C}$ in meat samples of $C$. carpio and $C$. gariepinus compared to $-21{ }^{\circ} \mathrm{C}$ stored sample was due to microbial and chemical changes were faster in the meat at $4{ }^{\circ} \mathrm{C}$ stored fish. The increase in $\mathrm{pH}$ in this experiment may be due to the fermentation of carbohydrate to acid as observed within the first week in the $-21{ }^{\circ} \mathrm{C}$ stored sample (Table 1). 
Table 1. pH levels of fresh and stored Catla catla and Labeo rohita.

\begin{tabular}{|c|c|c|c|c|c|c|}
\hline \multirow{3}{*}{$\begin{array}{l}\text { Storage time } \\
\text { (Weeks) }\end{array}$} & \multicolumn{3}{|c|}{ Labeo rohita } & \multicolumn{3}{|c|}{ Catla catla } \\
\hline & \multirow{2}{*}{$\begin{array}{c}\text { Fresh } \\
6.85 \pm 0.32\end{array}$} & \multicolumn{2}{|c|}{ Storage temperature } & \multirow{2}{*}{$\begin{array}{c}\text { Fresh } \\
6.87 \pm 0.22\end{array}$} & \multicolumn{2}{|c|}{ Storage temperature } \\
\hline & & $-21^{\circ} \mathrm{C}$ & $-4^{\circ} \mathrm{C}$ & & $-21^{\circ} \mathrm{C}$ & $-4^{\circ} \mathrm{C}$ \\
\hline 0 & & $6.85 \pm 0.32 \mathrm{cA}$ & $6.83 \pm 0.25 \mathrm{eA}$ & & $6.87 \pm 0.22 \mathrm{eA}$ & $6.87 \pm 0.22 \mathrm{fA}$ \\
\hline 1 & & $6.79 \pm 0.34 \mathrm{~dB}$ & $6.81 \pm 0.29 \mathrm{eB}$ & & $6.82 \pm 0.24 \mathrm{eA}$ & $6.85 \pm 0.28 \mathrm{fA}$ \\
\hline 2 & & $6.88 \pm 0.30 \mathrm{cC}$ & $7.02 \pm 0.34 \mathrm{dA}$ & & $6.93 \pm 0.31 \mathrm{~dB}$ & $7.01 \pm 0.38 \mathrm{eA}$ \\
\hline 3 & & $6.95 \pm 0.35 \mathrm{bD}$ & $7.14 \pm 0.26 \mathrm{cB}$ & & $7.02 \pm 0.35 \mathrm{cC}$ & $7.16 \pm 0.40 \mathrm{dA}$ \\
\hline 4 & & $6.99 \pm 0.37 \mathrm{bD}$ & $7.19 \pm 0.28 \mathrm{bB}$ & & $7.11 \pm 0.37 \mathrm{bC}$ & $7.22 \pm 0.35 \mathrm{cA}$ \\
\hline 5 & & $7.02 \pm 0.36 \mathrm{aD}$ & $7.23 \pm 0.36 \mathrm{bB}$ & & $7.15 \pm 0.41 b C$ & $7.28 \pm 0.42 \mathrm{bA}$ \\
\hline 6 & & $7.05 \pm 0.39 \mathrm{aD}$ & $7.31 \pm 0.41 \mathrm{aB}$ & & $7.21 \pm 0.43 \mathrm{aC}$ & $7.35 \pm 0.40 \mathrm{aA}$ \\
\hline
\end{tabular}

a-c Different letters in the same column indicate significant difference " $\mathrm{P}<0.05$ "; A-B Different letters in the same row indicate significant difference " $\mathrm{P}<0.05$ ".

\subsection{Proximate composition}

Proximate analysis of fish muscle of $C$. gariepinus and C. carpio exhibited a decrease in the crude protein and lipid content compared to the fresh fish from $2^{\text {nd }}$ to $6^{\text {th }}$ week (Tables 2, 3). The crude protein content in C. gariepinus in muscle samples stored at $-21{ }^{\circ} \mathrm{C}$ was observed to decrease from $15.44 \pm 0.70 \%$ to $9.62 \pm 0.78 \%$ after the sixth week of storage, while in fish muscle sample stored at $4{ }^{\circ} \mathrm{C}$ the crude protein decreased from $15.86 \pm 1.48 \%$ to $10.37 \pm 0.73 \%$ after the sixth week (Table 2 ). The crude protein content in C. carpio in muscle samples stored at $-21{ }^{\circ} \mathrm{C}$ was observed to decrease from $16.51 \pm 1.80 \%$ to $8.72 \pm 0.90 \%$ after the sixth week of storage. The crude protein decreased from $16.51 \pm 1.80 \%$ to $8.25 \pm 0.61 \%$ after the sixth week in the fish muscle sample stored at $4{ }^{\circ} \mathrm{C}$ (Table 3). Similarly, the lipid content in fish muscle samples of $C$. gariepinus stored at $-21{ }^{\circ} \mathrm{C}$ was decreased from $5.08 \pm 0.88 \%$ to $2.60 \pm 0.42 \%$, while in the same stored at $4{ }^{\circ} \mathrm{C}$ the lipid content was decreased from $5.08 \pm 0.88 \%$ to $2.93 \pm 0.66 \%$ after the sixth week (Table 2). The lipid content in the muscle samples of $C$. carpio stored at $-21^{\circ} \mathrm{C}$ was decreased from about $4.43 \pm 0.91 \%$ to $2.15 \pm 0.64 \%$, while in fish muscle samples stored at $4{ }^{\circ} \mathrm{C}$ the lipid content was decreased from $4.43 \pm 0.91 \%$ to $1.87 \pm 0.71 \%$ after the sixth week (Table 3 ). The moisture content in meat samples of $C$. gariepinus stored at $-21^{\circ} \mathrm{C}$ was decreased from $71.30 \pm 2.60 \%$ to $51.13 \pm 2.99 \%$, while in meat samples stored at $4{ }^{\circ} \mathrm{C}$ the moisture content was decreased from $71.30 \pm 2.60 \%$ to $52.18 \pm 2.70 \%$ after the sixth week (Table 2). The moisture content in meat samples of s C. carpio stored at $-21{ }^{\circ} \mathrm{C}$ was decreased from about $70.91 \pm 2.60 \%$ to $48.90 \pm 2.90 \%$, while in meat samples stored at $4{ }^{\circ} \mathrm{C}$ the moisture content was decreased from $70.91 \pm 2.60 \%$ to $51.25 \pm 2.84 \%$ after the sixth week (Table 3). Ash content of C. gariepinus stored at $-21{ }^{\circ} \mathrm{C}$ increased from $4.18 \pm 0.71 \%$ to $9.45 \pm 0.57 \%$, while for the $4{ }^{\circ} \mathrm{C}$ stored sample, ash content was increased from $4.18 \pm 0.71 \%$ to $9.21 \pm 0.70 \%$ after six weeks. Similarly, ash content in meat samples of C. carpio stored at $4{ }^{\circ} \mathrm{C}$ increased from $5.23 \pm 0.94 \%$ to $8.80 \pm 0.95 \%$, while for the muscle samples stored at $4{ }^{\circ} \mathrm{C}$ stored sample, the ash content increased from $5.23 \pm 0.94 \%$ to $9.21 \pm 0.70 \%$ after sixth weeks (Table 3). Statistical analysis of the constituents of proximate composition: crude protein, crude lipid, moisture and ash exhibited significant differences $(P<0.05)$ in the different compositions at the same storage temperatures and between the two temperatures in C. gariepinus and C. carpio (Tables 2, 3).

\subsection{Organoleptic evaluation}

The results of the present study showed a gradual reduction in the organoleptic characteristics such as color, texture, freshness and taste of C. gariepinus and C. carpio evaluated by a panel of trained judges (Tables 4, 5). The physical attributes such as color in C. gariepinus, the score reduced from $4.8 \pm 0.40$ to $1.9 \pm 0.27$ in the fish meat samples stored at $-21^{\circ} \mathrm{C}$ and from $4.8 \pm 0.40$ to $1.6 \pm 0.41$ in the $4{ }^{\circ} \mathrm{C}$ stored sample (Table 4). The grade for color of the meat of C. carpio was reduced from $4.9 \pm 0.55$ to $2.1 \pm 0.40$ in the fish meat samples stored at $-21{ }^{\circ} \mathrm{C}$ and from $4.9 \pm 0.55$ to $1.9 \pm 0.48$ in the $4{ }^{\circ} \mathrm{C}$ stored sample (Table 5). The grade for texture in C. gariepinus and C. carpio fluctuated from $5.5 \pm 0.85$ to $2.4 \pm 0.52$ and $5.9 \pm 0.90$ to $1.9 \pm 0.55$ in the meat samples stored at $-21{ }^{\circ} \mathrm{C}$ and from $5.5 \pm 0.85$ to $2.0 \pm 0.52$ and $5.9 \pm 0.90$ to $1.5 \pm 0.25$, respectively in the samples stored at $4{ }^{\circ} \mathrm{C}$ (Tables 4, 5). The grade for freshness in C. gariepinus and $C$. carpio dropped significantly from $5.7 \pm 0.48$ to $2.4 \pm 0.64$ and $5.8 \pm 0.70$ to $1.8 \pm 0.51$, respectively in the meat samples stored at $-21^{\circ} \mathrm{C}$. While the grade for freshness in the meat samples of $C$. gariepinus and C. carpio stored at $4{ }^{\circ} \mathrm{C}$ was dropped significantly from $5.7 \pm 0.48$ to $2.1 \pm 0.47$ and $5.8 \pm 0.70$ to $1.5 \pm 0.72$, respectively (Tables 4,5 ). The grade for taste in in the meat samples of C. gariepinus and C. carpio stored at $-21{ }^{\circ} \mathrm{C}$ dropped significantly from $5.6 \pm 0.98$ to $2.6 \pm 0.62$ and $5.9 \pm 0.88$ to $2.2 \pm 0.51$, respectively. While the score for taste in the meat samples of C. gariepinus and C. carpio stored at $4{ }^{\circ} \mathrm{C}$ dropped significantly from $5.6 \pm 0.98$ to $2.6 \pm 0.62$ and $5.9 \pm 0.88$ to $1.8 \pm 0.31$, respectively (Tables 4,5 ). The comparison of means for the four parameters studied for the organoleptic evaluation: color, texture, freshness and taste showed significant differences $(\mathrm{P}<0.05)$ in the organoleptic characters within the same storage temperatures 


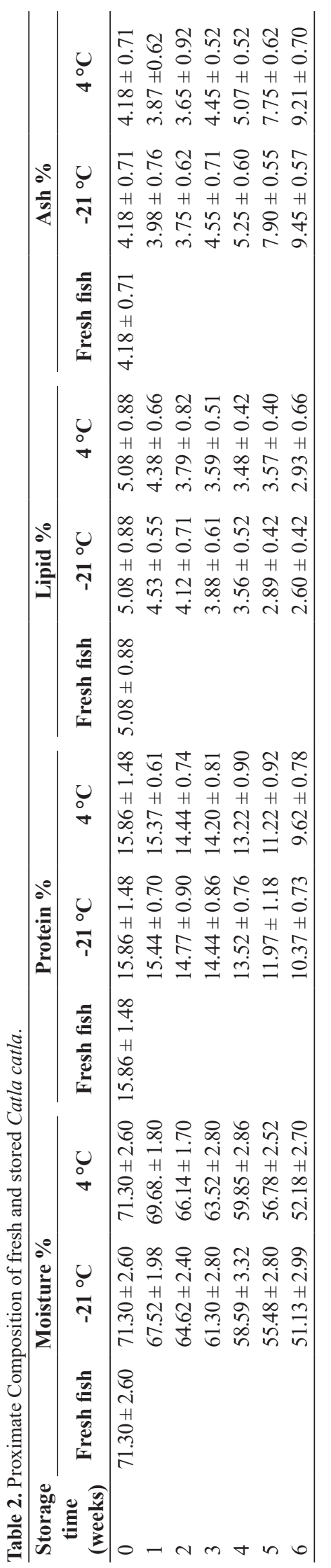

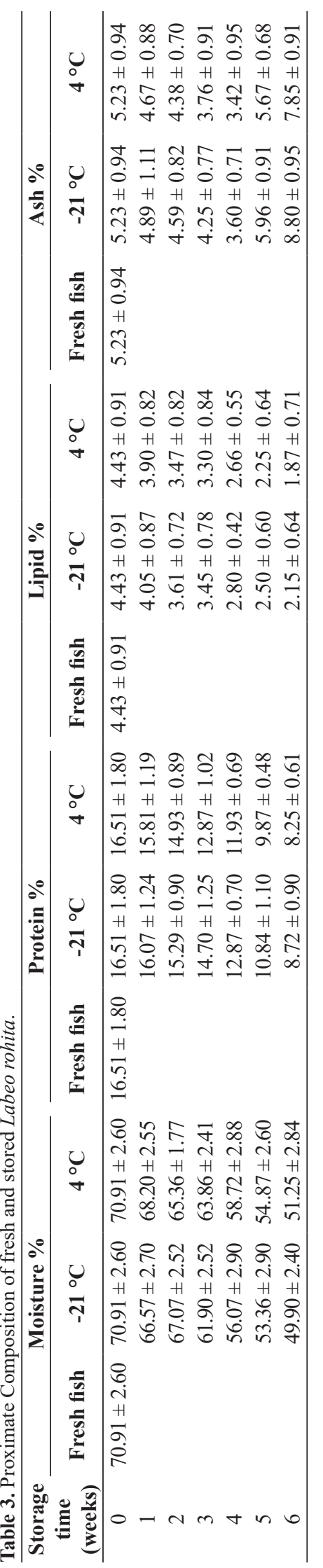



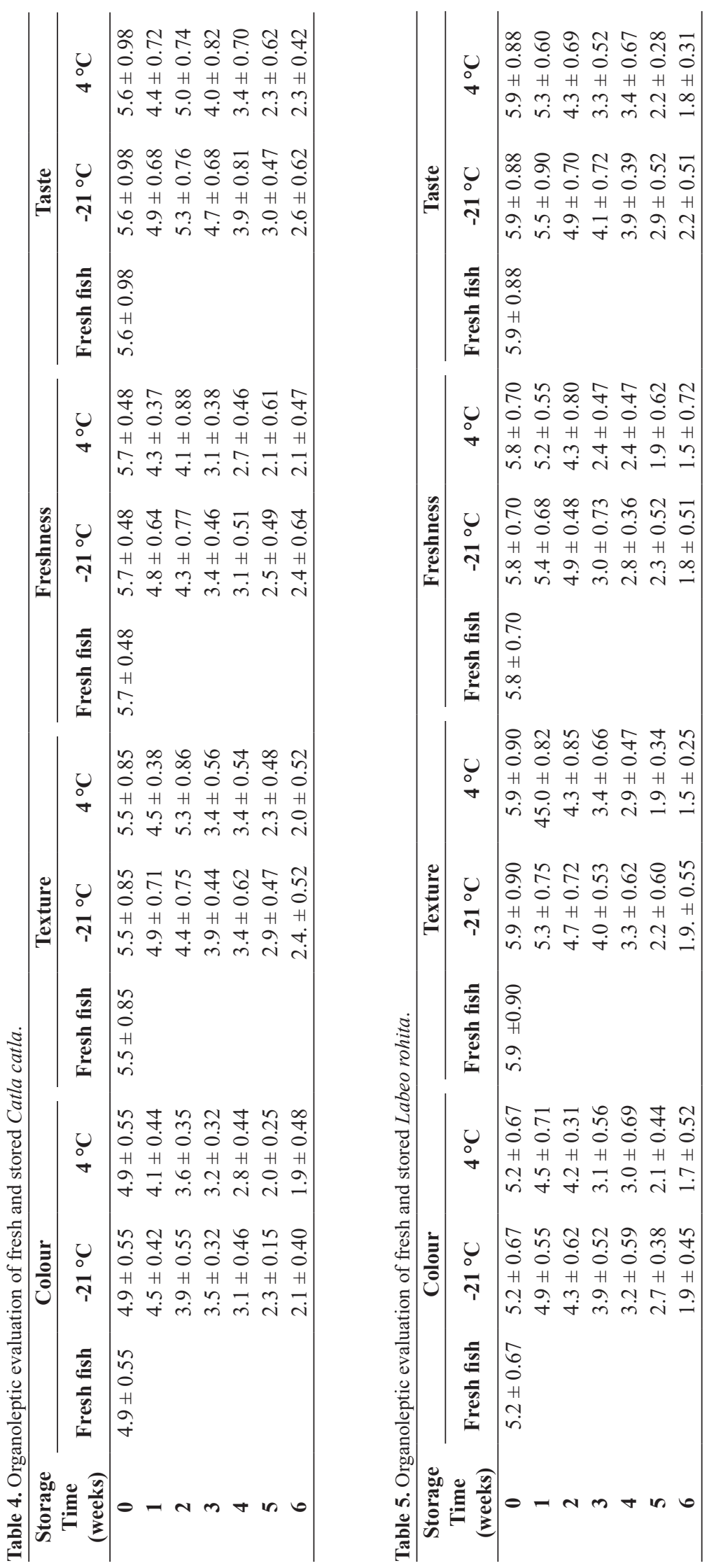
and among the freshest fish and stored at two temperatures and in the two fish species (Tables 4, 5).

\section{Discussion}

Eyo (2001) reported that $\mathrm{pH}$ might be used as an indicator to the extent of microbial spoilage in fish. This increase in $\mathrm{pH}$ may be due to increase in accumulation of ammonia compounds, mainly due to increased microbial activities. The increase in $\mathrm{pH}$ can also cause an increase in the volatile compounds due to decomposition of nitrogenous compounds by endogenous or microbial enzymes (Erkan and Ozden, 2008). Our results are in line with the findings of above-mentioned workers. Pacheco-Aguilar et al. (2000) reported $\mathrm{pH}$ as an index, which is important in the evaluation of the quality of fish. Iheanacho et al. (2017)

The decrease in crude protein in the two fish species during the storage could be due to the slow denaturation of the crude protein to more volatile compounds such as total volatile bases (TVB), trimethyl amine (TMA) hydrogen sulphide and ammonia. These findings were in line with the results reported by Eyo (2001). The variation in protein and lipid amount could be due to the leaching out of ice of few lipid constituents (Emokpae, 1979). The decrease in protein in the meat of fish could be due to reduction in salt and water soluble (Chomnawang et al., 2007) or because of autolytic degradation combine with endogenous enzymes and bacteria (Hultmann and Rustad, 2004). The decrease in protein content was probably due to leaching of soluble components especially water proteins and urea as fresh fish spoil in storage (Osibona and Ezekiel, 2014; Iheanacho et al., 2017).

The decrease in lipid content may be linked with the oxidation of polyunsaturated fatty acids found in fish tissues in other products such as aldehydes, free fatty acids, ketones, and peroxides (Horner, 1992; Mahboob et al., 2004). Ash content increased during the experimental period. The result of proximate analysis revealed that moisture formed the highest component of the proximate composition of C. gariepinus and C. carpio. The moisture content was observed to decrease considerably at $-21{ }^{\circ} \mathrm{C}$ stored samples, but decreased slightly in the $4{ }^{\circ} \mathrm{C}$ stored samples during the storage period, which is probably due to absorption of moisture from the cool atmosphere.

Organoleptic assessment in this study exhibited that the decline in the score of graded parameters such as: color, texture, freshness, and taste varied with storage temperature and time. This reduction may be due to the increasing activities of spoilage agents and the biochemical changes occurring therein with increasing time and as reported by Oriakpono et al. (2011). These changes were observed at the two storage temperatures, but occurred more sharply in the fish samples of C. gariepinus as compared to C. carpio stored $4{ }^{\circ} \mathrm{C}$ stored. The most pronounced changes were observed in freshness and taste which became unacceptable after three weeks of storage at $4{ }^{\circ} \mathrm{C}$ stored fish samples (Sahu et al., 2016; Yin et al., 2017). The judges' scores for color and texture also reduced within the range of very good before storage, to the poor range after six weeks in both the fish species. The comparison of two species also indicated some differences in, color, texture, freshness and taste that might be due to their inherent potential and $C$. carpio feeding niche. The texture of the body was loose and odor, increased in C. gariepinus and C. carpio at $4{ }^{\circ} \mathrm{C}$ and these changes were due to an increment of storage period (George and Gopakumar, 1988; Huss, 1995; Al-Ghanim, 2016; Sahu et al., 2016). Mchazime and Kapute (2018) mentioned that the processed fish were liked by the consumers up to 12 hours of ambient storage. They also reported a significant correlation between sensory scores and storage time at ambient temperature and suggested the time is important factor in maintain the freshness and quality of fish meat. The findings of this study were in line with the results of Mchazime and Kapute (2018). Increase in spoilage with the reduction of quality in the major substrates caused rapid deterioration of carps. The similar findings were also reported by Hassan (1996), Jayaram et al. (1980) and Tahir (2008). The organoleptic assessment has proven to be an invaluable tool in the evaluation of freshness of fishes. Different biochemical, physical (Gill, 1992, 1997; Mahboob et al., 2004; Agbabiaka et al., 2016) and microbiological methods (Al-Ghanim, 2016) are practical to determine freshness. The sensory evaluation of fish meat is still considered one of the most reliable method to determine the taste and flavor of fish meat (Hassan and Ali, 2011).

\section{Conclusion}

We concluded that there is a significant change in the $\mathrm{pH}$ and proximate composition of the fish meat with an increase in a storage time, even at these $\left(-21^{\circ} \mathrm{C}\right.$ and $\left.4{ }^{\circ} \mathrm{C}\right)$, which ultimately effect on the organoleptic quality of fish meat. However, more decline in the proximate composition and organoleptic parameters was observed in fish, meat samples of both the fish species stored at $4{ }^{\circ} \mathrm{C}$. Thus, it is better to either consume the fresh fish or is stored under freezing conditions on $-21^{\circ} \mathrm{C}$.

\section{Acknowledgements}

The authors (SM \& KAAG) would like to express their sincere appreciation to the Deanship of Scientific Research at King Saud University for its funding of this research through the Research Group Project No. Prolific Research Group No. 1436-011.

\section{References}

AGBABIAKA, L.A., KUFORIJI, O.A. and EGOBUIKE, C.C., 2016. Comparative studies on the nutrients, sensory and storage qualities of moon-fish (Citharinus citharus Geoffery SaintHilaire 1809) pre-treated with extracts from two spices. Journal of Aquatic Research Development, vol. 7, pp. 398. http://dx.doi. org/10.4172/2155-9546.1000398. 
AL-GHANIM, K.A., 2016. Effect of different storage temperatures on chemical composition and sensory attributes of the flesh of Cyprinus carpio and Clarias gariepinus. Pakistan Journal of Zoology, vol. 48, pp. 305-310.

ASSOCIATION OF OFFICIAL ANALYTICAL CHEMISTS - AOAC, 2000. Official methods of analysis of the Association of Official Analytical Chemists. 17th ed. Washington: AOAC, pp. 21-447.

AYISI, C.L., ZHAO, J. and RUPIA, E.J., 2017. Growth performance, feed utilization, body and fatty acid composition of Nile tilapia (Oreochromis niloticus) fed diets containing elevated levels of palm oil. Aquaculture and Fisheries, vol. 2, no. 2, pp. 67-77. http://dx.doi.org/10.1016/j.aaf.2017.02.001.

BRAUN, P. and SUTHERLAND, J.P., 2005. Predictive modelling of growth and measurement of enzymatic synthesis and activity by a cocktail of selected enterobacteriaceae and Aeromonas hydrophilia. International Journal of Food Microbiology, vol. 105, no. 2, pp. 257-266. http://dx.doi.org/10.1016/j.ijfoodmicro.2005.04.005. PMid:16154655.

CHOMNAWANG, C., NANTACHAI, K., YONGSAWATDIGUL, J., THAWORNCHINSOMBUT, S. and TUNGKAWACHARA, S., 2007. Chemical and biochemical changes in hybrid catfish fillet stored at $4{ }^{\circ} \mathrm{C}$ and its gel properties. Food Chemistry, vol. 103, no. 2, pp. 420-427. http://dx.doi.org/10.1016/j.foodchem.2006.07.039.

EMOKPAE, A.O., 1979. Organoleptic assessment of the quality of fresh fish. Nigeria: Nigerian Instute Oceanography Marine Research, pp. 1-4. Occasional Paper, no. 12.

ERKAN, N. and OZDEN, O., 2008. Quality assessment of whole and gutted sardines (Sardina pilchardus) stored in ice. International Journal of Food Sciences, vol. 13, no. 9, pp. 1549-1555. http:// dx.doi.org/10.1111/j.1365-2621.2007.01579.x.

EYO, A.A., 2001. Fish processing technology in the tropics. New Bussa: National Institute for Freshwater Fisheries Research, vol. 13.

GEORGE, C. and GOPAKUMAR, K., 1988. Spoilage changes in the muscle of crab, Scylla serrate stored at three different temperatures. In: M. JOSEPH, ed. The first Indian fisheries forum proceedings. Indian Branch: Asian Fisheries Society, pp. 347-349.

GILL, T.A., 1992. Biochemical and chemical indices of seafood quality. In: H.H. HUSS, M. JACOBSEN and J. LISTON, eds. Quality assurance in the fish industry. Amsterdam: Elsevier, pp. 377-388.

GILL, T.A., 1997. Advanced analytical tools in seafood science. In: J.B. LUTEN, N. BORRESEN and J. OEHLENSCHLAGER, eds. Seafood from producer to consumer: integrated approach to quality. Amsterdam: Elsevier Science, pp. 479-490. Developments in Food Science, no. 38.

GRAM, L. and HUSS, H.H., 1996. Microbiological spoilage of fish and fish products. International Journal of Food Microbiology, vol. 33, no. 1, pp. 121-137. http://dx.doi.org/10.1016/01681605(96)01134-8. PMid:8913813.

GRIGORAKIS, K., TAYLOR, K.D.A. and ALEXIS, M.N., 2003. Organoleptic and volatile aroma compounds comparison of wild and cultured gilthead sea bream (Sparus aurata): sensory differences and possible chemical basis. Aquaculture, vol. 225, no. 1-4, pp. 109-119. http://dx.doi.org/10.1016/S0044-8486(03)00283-7.

HASSAN, F. and ALI, M., 2011. Quality evaluation of some fresh and imported frozen seafood. Advance Journal Food Science Technology, vol. 3, pp. 83-88.
HASSAN, M., 1996. Influence of pond fertilization with broiler droppings on the growth performance and meat quality of major carps. Faisalabad: Department of Zoology \& Fisheries, University of Agriculture, 195 p. Ph.D. thesis.

HORNER, W.F.A., 1992. Preservation of fish by curing: fish processing technology. London: Chapman \& Hall.

HULTMANN, L. and RUSTAD, T., 2004. Iced storage of Atlantic salmon (Salmo salar) effects on endogenous enzymes and their impact on muscle proteins and texture. Food Chemistry, vol. 87, no. 1, pp. 31-34. http://dx.doi.org/10.1016/j.foodchem.2003.10.013.

HUSS, H.H., 1995. Quality changes in fresh fish. Rome: FAO. FAO Fisheries Technical Paper, no. 348.

IHEANACHO, S.C., NWORU, S.A., OGUEJI, E.O., NNATUANYA, I., MBAH, C.E., ANOSIKE, F., OKOYE, C., IBRAHIM, U.B., KOGI, E. and HARUNA, M., 2017. Comparative assessment of proximate content and organoleptic quality of African catfish (Clarias gariepinus) processed by smoking and solar drying methods. African Journal of Agricultural Research, vol. 12, no. 38, pp. 2824-2829. http://dx.doi.org/10.5897/AJAR2017.12599.

JAYARAM, M.G., SCHETTY, H.P.C. and UDUPA, K.S., 1980. Organoleptic evaluation of flesh of carps fed on different kinds of feed. Mysore Journal of Agricultural Sciences, vol. 14, pp. 421-424.

MAHBOOB, S., 2014. Effect of feed supplementation formulated from different plant sources on the growth performance of Cirrhinus mrigala and Cyprinus carpio. Afinidad, vol. 80, pp. 154-158.

MAHBOOB, S., LIAQUAT, F., LIAQUAT, S., HASSAN, M. and RAFIQUE, M., 2004. Proximate composition of meat and dressing losses of wild and farmed Labeo rohita (Rohu). Pakistan Journal of Zoology, vol. 36, pp. 39-43.

MAHBOOB, S., SHERI, A.N. and RAZA, S.H., 1996. Proximate composition of major common and some Chinese carp as influenced by pond fertilizer and feed supplementation in composite culture system. Journal of Aquaculture in the Tropics, vol. 11, pp. 227-284.

MCHAZIME, I. and KAPUTE, F., 2018. Sensory and nutrient quality of wild captured Oreochromis shiranus (Boulenger, 1897) stored at ambient temperature. International Food Research Journal, vol. 25, no. 1, pp. 127-132.

MEYERS, S.P., 1975. Aquaculture and fish/Crustacean offflavour. Rome: FAO, pp. 24.

NARGIS, A., 2006. Seasonal variation in the chemical composition of body flesh of koi fish Anabas testudineus (Bloch) (Anabantidae: Percifomes). Bangladesh Journal of Scientific and Industrial Research, vol. 41, pp. 219-226.

NDOME, C., ORIAKPONO, O. and AGNES, O., 2010a. Proximate composition and nutritional value of some commonly consumed fishes in Calabar. Journal of Tropical Freshwater Biology, vol. 19, pp. 11-18.

NDOME, C., ORIAKPONO, O., ASITOK, A. and AFFIONG, E., 2010b. Microbial content of fresh Chrysichthys nigrodigitatus (Catfish) and Oreochromis niloticus (Tilapia) in Calabar beach. African Journal of Applied Zoology Environmental Biology, vol. 12 , pp. 82-86.

ORIAKPONO, O., FRANK-PETERSIDE, N. and NDOME, C., 2011. Microbiological assessment of stored Tilapia guineensis. African Journal of Food Science, vol. 5, pp. 242-247.

OSIBONA, A.O. and EZEKIEL, M.O., 2014. Chemical, sensory and microbiological changes of spotted gruntter (Pomadasys commersonnii) under ice storage. African Journal of Food, 
Agriculture, Nutrition and Development, vol. 14, no. 6, pp. 2141-2160.

PACHECO-AGUILAR, R., LUGO-SANCHEZ, M.E. and ROBLES-BURGUENO, M.R., 2000. Postmortem biochemical characteristics of Monterey sardine muscle stored at $0^{\circ} \mathrm{C}$. Journal of Food Science, vol. 65, no. 1, pp. 40-47. http://dx.doi. org/10.1111/j.1365-2621.2000.tb15953.x.

SAHU, R.K., DESHMUKH, V.V., BHONG, C.D., YEOTIKAR, P.V. and VAIDYA, M.S., 2016. Organoleptic, physcico-chemical, and microbial qualities of freshwater fish (Catla catla) at various storages of supply chain vended in retail fish market. Animal Science Reporter, vol. 10, pp. 123-131.

SHERRATT, T.N., WILKINSON, D.M. and BAIN, R.S., 2006. Why fruits rot, seeds mold and meat spoils: a reappraisal. Ecological Modelling, vol. 192, no. 3-4, pp. 618-626. http:// dx.doi.org/10.1016/j.ecolmodel.2005.07.030.
TAHIR, M.Z.I., 2008. Studies on partial replacement of fishmeal with oil seed meals in the diet of major carps in semi-intensive culture system. Faisalabad: Department of Zoology \& Fisheries, University of Agriculture, pp. 174-178. Ph.D. thesis.

THOMAS, N.A., 1973. Assessment of fish flesh tainting substances. In: J. CAIRNS and K.L. DICKSON, eds. ASTM STP 528: biological methods for the assessment of water quality. Philadelphia: American Society for Testing and Materials, pp. 178-193. http://dx.doi.org/10.1520/STP34724S.

TSIRONI, T. and TAOUKIS, P.S., 2017. Effect of storage temperature and osmotic pre-treatment with alternative solutes on the shelf-life of gilthead seabream (Sparus aurata) fillets. Aquaculture and Fisheries, vol. 2, no. 1, pp. 39-47. http://dx.doi. org/10.1016/j.aaf.2016.10.003.

YIN, Y., GAOI, J. and LIU, Y., 2017. Influence of industrial organizational structure on farming performance of large yellow croaker farmers. Aquaculture and Fisheries, vol. 2, no. 3, pp. 134-139. http://dx.doi.org/10.1016/j.aaf.2017.04.002. 